\title{
SYMBIOSIS OF RHIZOBIUM LEGUMINOSARUM BV. TRIFOLII WITH RED CLOVER VARIETIES
}

\author{
O. O. Kichigina ${ }^{1}$, V. P. Patyka ${ }^{2}$ \\ ${ }^{1}$ Institute of Agroecology and Environmental Management, NAAS, Kyiv \\ 12, Metrolohichna Str., Kyiv City, 03143, Ukraine e-mail: ol_ki@ukr.net \\ ${ }^{2}$ Danylo Zabolotny Institute of Microbiology and Virology, NAS of Ukraine, Kyiv \\ 154, Zabolotnoho Str., Kyiv City, 03143, Ukraine
}

Biological nitrogen is a powerful factor in improving potential soil fertility, significant saving of mineral nitrogen fertilizers, reducing pollution of environment by harmful nitrogen compounds [7].

More than half of fixed nitrogen on the planet is bound through functioning the symbiosis of legumes and nodule bacteria, and in soil and climatic conditions of Ukraine, depending on legumes that are grown, legume-rhizobial systems are able to fix from 40 to $300 \mathrm{~kg}$ or more of nitrogen per 1 hectare of crops from the atmosphere yearly $[1 ; 8$; 12]. According to A. O. Babych [10], red clover shows the productivity of nitrogen fixation of $115-208 \mathrm{~kg}$ of nitrogen/ha per year, while the proportion of biological nitrogen in the formation of yield reaches 70$90 \%$, the balance of nitrogen in the soil -60 $80 \mathrm{~kg} / \mathrm{ha}$.

Thus, red clover, in addition to its value as a high-protein crop has important agrotechnical value. It accumulates biologically fixed nitrogen in the soil, fertilizes soil due to plant debris, and improves its structure, being as a result a good forecrop for all crops. Its use both in pure sowing and in mixtures with grasses enhances the productivity and quality of feed [9]. Therefore, at the formation of vegetation particular attention should be paid to the introduction of red clover varieties with high potential for nitrogen fixation into grass mixtures [3].

It should be taken into consideration that the interaction between macro- and micro-symbionts is not always characterized by high efficiency of fixation of molecular nitrogen. It is known that the efficiency level of legume-rhizobial symbiosis is defined by genotypes of both partners - nodule bacteria and legume plants-feeders $[1 ; 8 ; 11]$.
Polymorphism by the activity of a symbiotic complex "legume - nodule bacteria" includes two aspects: variability and diversity of nodule bacteria strains and different reactions of a plant-feeder to the interaction with the bacterial strain. Therefore, high performance of symbiotic nitrogen fixation is not possible without aimed breeding of the varieties of legumes and complementary strains of nodule bacteria given specific climatic and agronomic soil and agrotechnical conditions.

The development of nodule bacteria is closely related to the growth of legume plants. Its genotype determines specific energy supply for the needs of nitrogen-fixing microorganism as the products of photosynthesis and root residues, as well as regulatory, warning and synanthropic processes of interaction [12]. Therefore, when red clover varieties are used in agriculture the features that characterize the ability to fix atmospheric nitrogen, except for their commercially valuable ones, should be considered.

The goal of our study was to estimate nitrogen fixation process intensity in red clover plants in symbiosis with Rhizobium leguminosarum $b v$. trifolii strain $329 \mathrm{~b}$ and allocation of donor genotypes of clover according to this indicator as well as seed yield.

Field small-plot experiment with the varieties of red clover ( $T$. pratense L.) was conducted at the Institute of Feed of NAAS (2006-2008). Soil - gray forest podzolic middle-loam; humus content - 2.06\%; $\mathrm{pH}$ 4.8; hydrolytic acidity -3.24 meq./100 g of soil; amount of absorbed bases - $19.2 \mathrm{mg}$ $\mathrm{Eq} / 100 \mathrm{~g}$ of soil; content of nitrogen available for plants - $74 \mathrm{mg} / \mathrm{kg}$ of soil (by Kornfield); 
labile phosphorus - $173 \mathrm{mg} / \mathrm{kg}$ of soil and exchangeable potassium $-88 \mathrm{mg} / \mathrm{kg}$ of soil (by for Kirsanov). Area of a research plot was $2 \mathrm{~m}^{2}$. Repetition of the experiment - six times.

The study was conducted in the crops of red clover of the second year of cultivation.

Nitrogenase activity was determined by using a gas chromatograph "Chrom 5" with ionizing flame detector [13]. The number of nodules on the roots of plants - visually by direct calculation. The study was conducted in the second week of June.

Collection and recording of seeds yield was carried out in August.

Detection of the probability of the obtained results was performed using standard computer programs "Statistics" by Student factor - in the laboratory experiments and by Fischer factor - in the field ones, using the recommendations of guidebooks on mathematical analysis of experiment results $[2 ; 5 ; 6]$.
The estimation of nitrogen fixation process intensity in meadow clover plants in symbiosis with Rhizobium leguminosarum $b v$. trifolii strain 329b, active agent of Rhyzobofit preparation, was performed. Plant varieties that were characterized with the greatest symbiotic and nodulation ability as well as seed productivity within the three years were selected.

The increase in Poltava 75 variety share in the area of forest steppe of Ukraine, and Anitra, Marusia, Myronivska 5, Milvus, Nosivska 5, Sparta varieties share in the area of both forest-steppe and Polissia in the crops of red clover as varieties with high nitrogenfixing potential will help to get feeds of high quality, solve the problems of shortage of protein in animal feed, improve soil fertility and ultimately - save a significant amount of mineral nitrogen fertilizers that will improve environmental conditions in agroecosystems in general. 